\title{
Tospoviruses Strike the Greenhouse Industry INSV Has Become a Major Pathogen on Flower Crops
}

$\mathbf{I}$ the late 1980 s, a significant new virus disease problem began to develop in the greenhouse floriculture industry. Dramatic and unusual symptoms suddenly appeared in many flower crops (Fig. 1). Infected plants were frequently exchanged between businesses during normal trade. In some cases, the symptoms were strongly indicative of virus infection, but in others, they resembled phytotoxic responses to pesticide sprays or air pollution. Symptoms were diverse, even within a single crop, and many different species were affected. The diverse symptoms were typical of tomato spotted wilt virus: stunting, necrotic and chlorotic spotting, stem cankers, line patterns, and ring spots. Because the disease could so easily be mistaken for a cultural or environmentally induced problem, attempts at on-site identification often were far off the mark.

Tomato spotted wilt tospovirus (TSWV) has been known as a pathogen of a wide range of ornamental, vegetable, and field crops for the better part of this century, but this virus was not previously associated with major losses in flower crops in the United States. The recent serious threat is

Dr. Daughtrey's address is: Department of Plant Pathology, L. I. Horticultural Research Laboratory, Cornell University, Riverhead, NY 11901;

E-mail: mld9@ cornell.edu

Publication no. D-1997-0918-01F

(C) 1997 The American Phytopathological Society undoubtedly related to the sudden dramatic problems with western flower thrips (WFT) (Frankliniella occidentalis Pergande) in greenhouses in the late 1980s (Fig. 2). This thrips, a TSWV vector, quickly became the most common and difficult-to-control pest in the greenhouse industry nationwide. As WFT spread, epidemic virus losses in greenhouses occurred across North America.

The new virus problem has been challenging to diagnosticians, as well as to growers. Antisera to TSWV did not always react with tissue from the affected plants. Research directed at an improved understanding of this and other anomalies presented by the pathogen determined that the virus outbreaks were not due to TSWV alone, but also to a second, closely related virus, initially designated TSWV-I but later named impatiens necrotic spot virus (INSV) (20). This second virus, like TSWV, was vectored by the western flower thrips and had a wide host range. The two viruses and other close relatives have since been assigned to the genus Tospovirus. Although there are a number of tospoviruses known to infect various agricultural crops around the world, to date only TSWV and INSV have been associated with disease outbreaks in North American and European greenhouse flower crops. Together, these two viruses have greatly influenced greenhouse flower crop selection and disease and insect management priorities over the past decade.
Of the two tospoviruses, INSV is currently the more commonly encountered threat within the greenhouse, while TSWV is more problematic on outdoor vegetable and field crops in areas where the virus is endemic: tobacco, tomato, pepper, and peanut, in particular, are dramatically affected by TSWV (Table 1). Although tomato and pepper are susceptible to INSV, on these two species, symptoms from INSV are usually less severe than those caused by TSWV (Table 2). Virus management problems in ornamentals can have a negative impact on the vegetable industry as well: flower and vegetable transplants are often produced together in the same greenhouse, providing an opportunity for transmission of tospoviruses from vegetatively propagated ornamentals to fieldgrown vegetables. Less than $20 \%$ of greenhouse flower crop tospovirus problems have been identified as TSWV; INSV

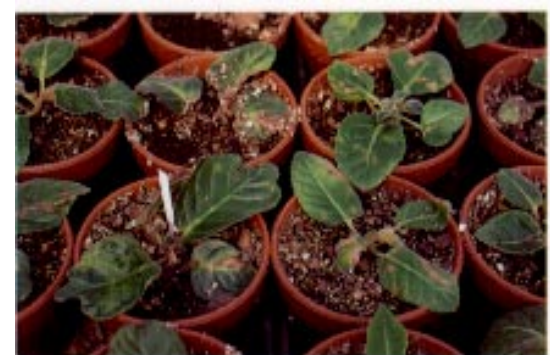

Fig. 1. Gloxinia crop devastated by impatiens necrotic spot tospovirus (INSV). 
predominates $(9,16)$. On the other hand, INSV has only rarely been detected in field-grown vegetable crops, and in several of these cases, the source has been traced to greenhouse-grown transplants.

This article will explore the impact of tospovirus diseases on the greenhouse flower industry and describe the development of our understanding of their identification and management in greenhouse flower crop production.

\section{Impact}

Over the past decade, INSV has caused significant crop losses for growers of major flower crops, including cineraria (Pericallis $\times$ hybrida R. Nordenstam), ranunculus (Ranunculus asiaticus L.), impatiens (Impatiens wallerana Hook f.), New Guinea impatiens (Impatiens hybrids), cyclamen (Cyclamen persicum Mill.), exacum (Exacum affine Balf. f.), begonia (Begonia Tuberhybrida hybrids), primula (Primula spp. and hybrids), and gloxinia (Sinningia speciosa (Lodd.) Hiern). Dozens of minor crop species have also been affected (Figs. 3 and 4). Although TSWV has been problematic in chrysanthemum and tuberous dahlias (Fig. 5 ), it has only occasionally been detected in other greenhouse flower crops.

Tospovirus losses in the state of Pennsylvania alone, during 1989 to 1990 , were estimated to be in excess of $\$ 675,000$ (retail value), over half of which was due to extensive roguing of diseased cineraria infected with INSV (16). In 1995, one East Coast grower reported disposing of 30,000 potted exacum $(\$ 150,000$ wholesale value) after thrips transferred INSV from a small group of infected begonias, while a West Coast ranunculus grower lost a crop valued at $\$ 63,000$ (wholesale) to INSV. Some
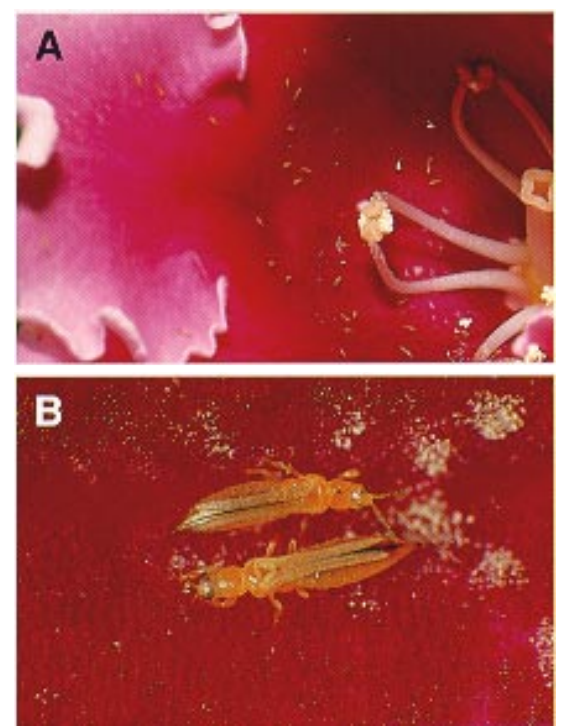

Fig. 2. Western flower thrips (Frankliniella occidentalis), the primary vector of tospoviruses in greenhouses. (A) Thrips adults at center of gloxinia flower; (B) close-up of adult females. greenhouse flower crops are highly virussensitive, while others may be chronically infected without noticeable symptoms; both may serve as inoculum sources. Gloxinia is probably the most acutely sensitive flower crop: young seedlings are killed outright by tospovirus; plants in- fected at a later stage of development exhibit crown rot, line patterns, mosaic, or round, brown leaf spots (Fig. 1). More than one gloxinia grower has experienced a $100 \%$ crop loss from INSV. One of the effects of tospoviruses has been a shift in the crops that growers produce: many have

Table 1. Number of positive tospovirus identifications from ornamental, vegetable, and field crops at the Plant Disease and Insect Clinic of North Carolina State University ${ }^{\mathrm{a}}$

\begin{tabular}{ccccccccc}
\hline & \multicolumn{3}{c}{ Impatiens necrotic spot } & & \multicolumn{3}{c}{ Tomato spotted wilt } \\
\cline { 2 - 3 } \cline { 6 - 8 } & Orn. & Veg. $^{\mathrm{b}}$ & Field $^{\mathrm{c}}$ & & Orn. & Veg. & Field $^{\mathrm{c}}$ \\
\hline 1989 & 28 & 0 & 0 & & 0 & 6 & 7 \\
1990 & 59 & 0 & 0 & & 0 & 10 & 36 \\
1991 & 19 & 2 & 0 & & 0 & 5 & 56 \\
1992 & 23 & 0 & 0 & & 0 & 7 & 48 \\
1993 & 23 & 0 & 0 & & 3 & 5 & 21 \\
1994 & 18 & 0 & 0 & & 0 & 12 & 37 \\
1995 & 16 & 0 & 0 & & 0 & 42 & 52 \\
1996 & 12 & 1 & 0 & & 0 & 17 & 13 \\
Total & 198 & 3 & 0 & & 3 & 104 & 270 \\
\hline
\end{tabular}

a Identification was primarily by enzyme-linked immunosorbent assay (ELISA).

b Tomato and pepper samples.

Tobacco and peanut samples.

Table 2. Symptoms of impatiens necrotic spot virus (INSV) and tomato spotted wilt virus (TSWV) in various hosts ${ }^{\mathrm{a}}$

\begin{tabular}{|c|c|c|}
\hline Host & INSV & TSWV \\
\hline $\begin{array}{l}\text { Nicotiana tabacum L. } \\
\text { 'Burley 21' (tobacco) }\end{array}$ & Local lesions (some isolates) & $\begin{array}{l}\text { Necrotic to chlorotic ring spots } \\
\text { on inoculated leaves; } \\
\text { systemic; young plant may } \\
\text { die, older plant may recover }\end{array}$ \\
\hline $\begin{array}{l}\text { N. benthamiana Domin } \\
\text { (tobacco) }\end{array}$ & $\begin{array}{l}\text { Chlorotic to necrotic ring spots } \\
\text { on inoculated leaves; systemic } \\
\text { chlorosis; stunting; young } \\
\text { plants die, older plants } \\
\text { recover }\end{array}$ & Same \\
\hline $\begin{array}{l}\text { Lycopersicon esculentum } \\
\text { Mill. (tomato) }\end{array}$ & $\begin{array}{l}\text { Variable between isolates; } \\
\text { lesions on inoculated leaves } \\
\text { only }\end{array}$ & $\begin{array}{l}\text { Chlorotic to necrotic spots and } \\
\text { rings on inoculated leaves; } \\
\text { systemic mosaic; systemic } \\
\text { chlorosis and necrotic spotting }\end{array}$ \\
\hline $\begin{array}{l}\text { Datura stramonium } \mathrm{L} . \\
\text { (datura) }\end{array}$ & Local lesions (some isolates) & $\begin{array}{l}\text { Chlorotic and necrotic spots } \\
\text { and rings on inoculated leaves; } \\
\text { systemic mosaic and mottle }\end{array}$ \\
\hline $\begin{array}{l}\text { Sinningia speciosa } \\
\text { (Lodd.) Hiern (gloxinia) }\end{array}$ & $\begin{array}{l}\text { Chlorotic to necrotic spots and } \\
\text { rings on inoculated leaves; } \\
\text { systemic chlorosis to necrosis; } \\
\text { young plants may die, older } \\
\text { plants may recover }\end{array}$ & Same \\
\hline $\begin{array}{l}\text { Dendranthema } \times \\
\text { grandiflorum Kitam. } \\
\text { (chrysanthemum) }\end{array}$ & $\begin{array}{l}\text { Chlorotic spots with necrotic } \\
\text { flecks on inoculated leaves } \\
\text { (not systemic) }\end{array}$ & $\begin{array}{l}\text { Chlorotic to necrotic spots on } \\
\text { inoculated leaves; systemic } \\
\text { symptoms: leaf collapse, } \\
\text { veinal necrosis, stem necrosis, } \\
\text { flower tilts to side; may kill } \\
\text { young plants }\end{array}$ \\
\hline $\begin{array}{l}\text { Petunia } \times \text { hybrida Vilm. } \\
\text { (petunia) }\end{array}$ & $\begin{array}{l}\text { Small necrotic spots on } \\
\text { inoculated leaves (not } \\
\text { systemic) }\end{array}$ & $\begin{array}{l}\text { Same but spots may be larger } \\
\text { (not systemic) }\end{array}$ \\
\hline $\begin{array}{l}\text { Impatiens wallerana } \\
\text { Hook f. (impatiens) }\end{array}$ & $\begin{array}{l}\text { Chlorotic to necrotic spots or } \\
\text { rings on inoculated leaves; } \\
\text { systemic chlorotic to necrotic } \\
\text { spots }\end{array}$ & Same \\
\hline
\end{tabular}

a Symptoms vary greatly among isolates and are affected by host cultivar, age of plant at inoculation, temperature, and so on. 
abandoned gloxinia and exacum production because of their attractiveness to western flower thrips and their high degree of injury from the viruses. INSV has become pervasive in the greenhouse industry: in a survey of 72 Massachusetts greenhouses, 42 were found to have plants that tested positive for INSV (30).

Roses (Rosa hybrids) and poinsettias (Euphorbia pulcherrima Willd. ex Klotzsch) are the only major flower crops not susceptible to INSV or TSWV. (Note that these are woody plants; tospoviruses are usually associated with herbaceous hosts.) There have been no significant crop losses in geraniums (Pelargonium spp.) from tospoviruses, even though INSV and TSWV have occasionally been detected in both florist's geranium (Pelargonium $\times$ hortorum L.H. Bailey) and ivy geranium (Pelargonium peltatum (L.) L'Her.). As new herbaceous crops become popular in the greenhouse industry, their susceptibility to tospoviruses often quickly becomes apparent (9).

\section{Detection and Diagnosis}

Greenhouse flower crop samples received by diagnostic labs usually include a high proportion of plants affected by abi-
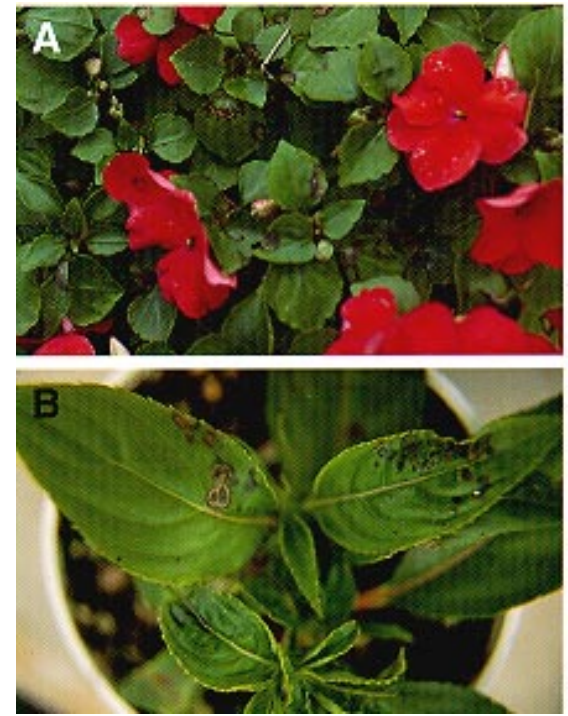

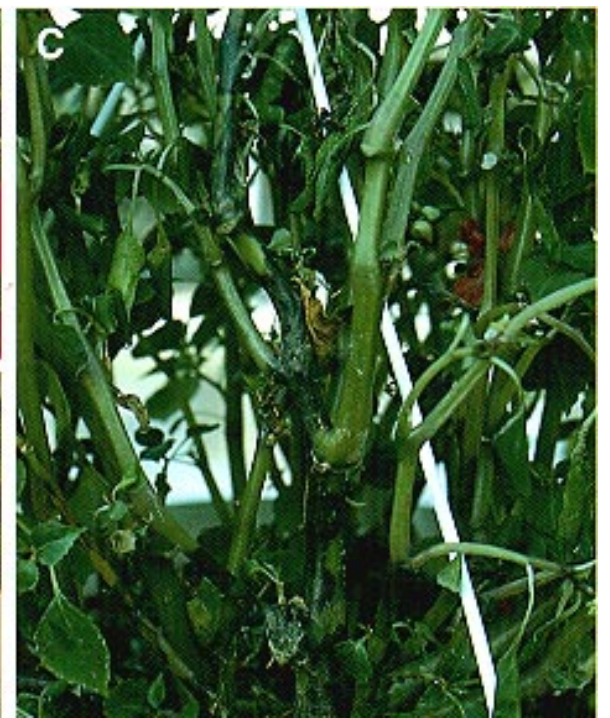

Fig. 3. Symptoms of impatiens necrotic spot tospovirus (INSV) on Impatiens. (A) Black rings and line patterns on the popular bedding plant, Impatiens wallerana Hook f.; (B) necrotic spots and blotches on New Guinea impatiens (Impatiens hybrid) grown as a potted plant; (C) black stem necrosis on a double-flowered impatiens (I. wallerana).
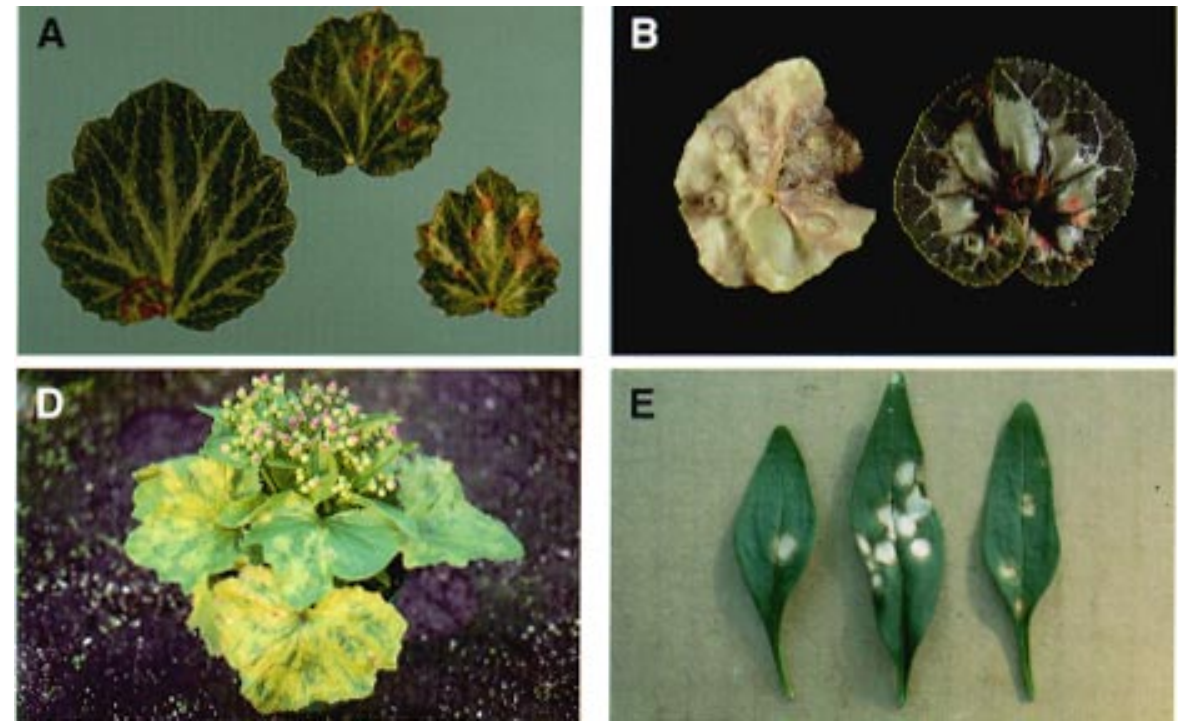

otic, fungal, and bacterial diseases. Viruses have rarely been a problem for flower growers, particularly since the development in the 1960s of clean-stock programs, which include virus-indexing for major vegetatively propagated crops such as geraniums and chrysanthemums. This picture changed radically as tospoviruses and western flower thrips came on the scene in the late 1980s. Tospoviruses infected a wide range of crops, with symptoms ranging from subtle to severe, from easily identifiable ring spots to necrotic spots or extensive foliar necrosis, which were likely to be misattributed to chemical injury or bacterial or fungal pathogens. As other possibilities were ruled out, diagnosticians tried mechanical transmission to indicator plants to test for the possibility of a virus as the cause.

Mechanical transmission from floral crops proved to be very difficult for INSV and gave erratic results for various reasons. First, INSV does not infect many of the traditional virus indicator plants, such as Burley tobacco (Nicotiana tabacum L.). Fortunately, another tobacco species, Nicotiana benthamiana Domin, was eventually discovered to be a good indicator (Fig. 6). Because INSV is very labile, mechanical transmission was difficult, particularly in hot weather. For reliable mechanical transmission during summer months in North Carolina, it is necessary to grind plant tissue in a buffer with reducing agents in ice and inoculate young $N$. benthamiana in the early morning. Young $N$. benthamiana plants develop chlorotic rings and spots 3 days after leaf inoculation. After the infection becomes systemic, the upper leaves and growing point develop chlorotic and necrotic flecks, and the plants wilt within 7 to 10 days. Once a
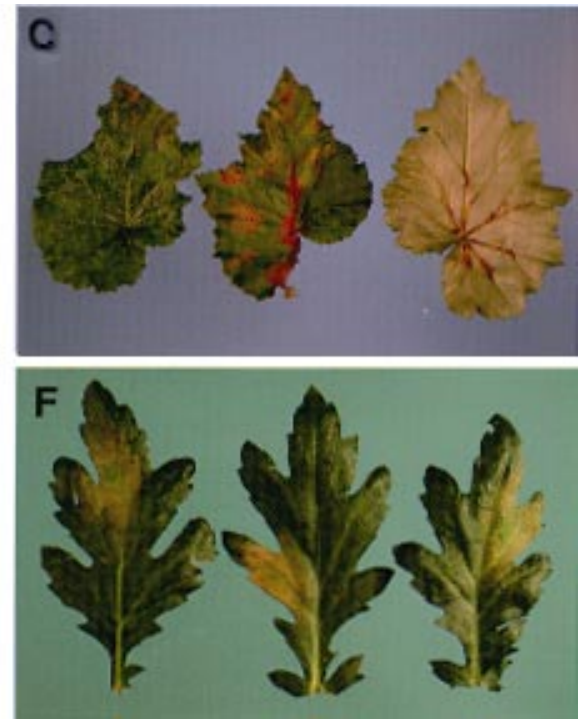

Fig. 4. Symptoms of impatiens necrotic spot tospovirus (INSV) on greenhouse flower crops. (A) Strawberry begonia (Saxifraga stolonifera Meerb.) and (B) cyclamen (Cyclamen persicum Mill.) with necrotic spots and ring spots; (C) begonia (Begonia Tuberhybrida hybrid) leaves with mottling, necrotic veins, and spots; (D) cineraria (Pericallis $\times$ hybrida R. Nordenstam) with systemic chlorotic mottle; (E) snapdragon (Antirrhinum majus L.) with white leaf spots; (F) chrysanthemum (Dendranthema $\times$ grandiflorum Kitam.) with flecked, bronzed patches. 
reliable bioassay technique using $N$. benthamiana was established, numerous samples of symptomatic plants from many states were assayed at North Carolina State University for INSV.

Bioassays on $N$. benthamiana were crucial to early diagnoses of INSV because only antiserum for TSWV was available, and it reacted either weakly or not at all with INSV. In some cases, passage through $N$. benthamiana was found to facilitate detection of INSV by TSWV antiserum. Because of their similarities, the two viruses were for some time thought to be two strains of one virus, termed TSWV-L for the original lettuce-type isolate and TSWV-I for the new impatiens type that reacted only weakly to TSWV antiserum. In 1989, an antiserum that was specific for INSV was produced, a major step forward in the clinical detection of the virus that was already having a major impact on the greenhouse flower industry. The new antiserum greatly facilitated diagnosis of INSV across the world, particularly after it became commercially available in 1989 (Agdia, Inc., Elkhart, IN) as a multi-well enzyme-linked immunosorbent assay (ELISA) kit. In 1995, an ELISA kit for tospovirus was produced that reacted with both INSV and TSWV (QTA-Tospo, Agdia) and was designed for use by the grower or IPM scout on-site. ELISA may also be used to specifically detect individual thrips that contain the TSWV NSs protein (nonstructural protein encoded by the S RNA), which marks them as competent vectors (4).

Additional techniques for INSV identification, less available than ELISA technology to most diagnostic labs, include direct tissue blot assay and dot blot immunoassay (17), as well as examination of plant tissue for characteristic viral inclusions (6) (Fig. 7). Dot blot immunoassays may have greater sensitivity than ELISA. The tissue blot technique allows samples to be collected on membranes on-site and then shipped to a lab for analysis. Groups of cells infected with tospovirus can be visualized by this method.

Whatever technique is used, it is critical to carefully select the tissue for diagnostic tests. INSV does not spread uniformly throughout plants that are "systemic hosts." Tissue should be selected from symptomatic parts of the plant, either chlorotic tissue or green tissue adjacent to necrotic tissue. Root or petal tissue may also be used for diagnostic tests with some hosts.

Currently, at the Plant Disease and Insect Clinic at North Carolina State University and a number of other laboratories, samples suspected of being infected with INSV or TSWV are generally tested for both viruses using multi-well ELISA kits. Since knowing which virus is present influences management decisions, growers using an on-site test kit may want to follow up with a test at a diagnostic lab that distinguishes among TSWV, INSV, and mixed infections.

\section{Molecular Biology of Impatiens Necrotic Spot Virus}

INSV was the second plant virus to be recognized as a member of the genus Tospovirus (20). The discovery and subsequent characterization of INSV contributed to our understanding of the diversity of TSWV and similar viruses. The molecular
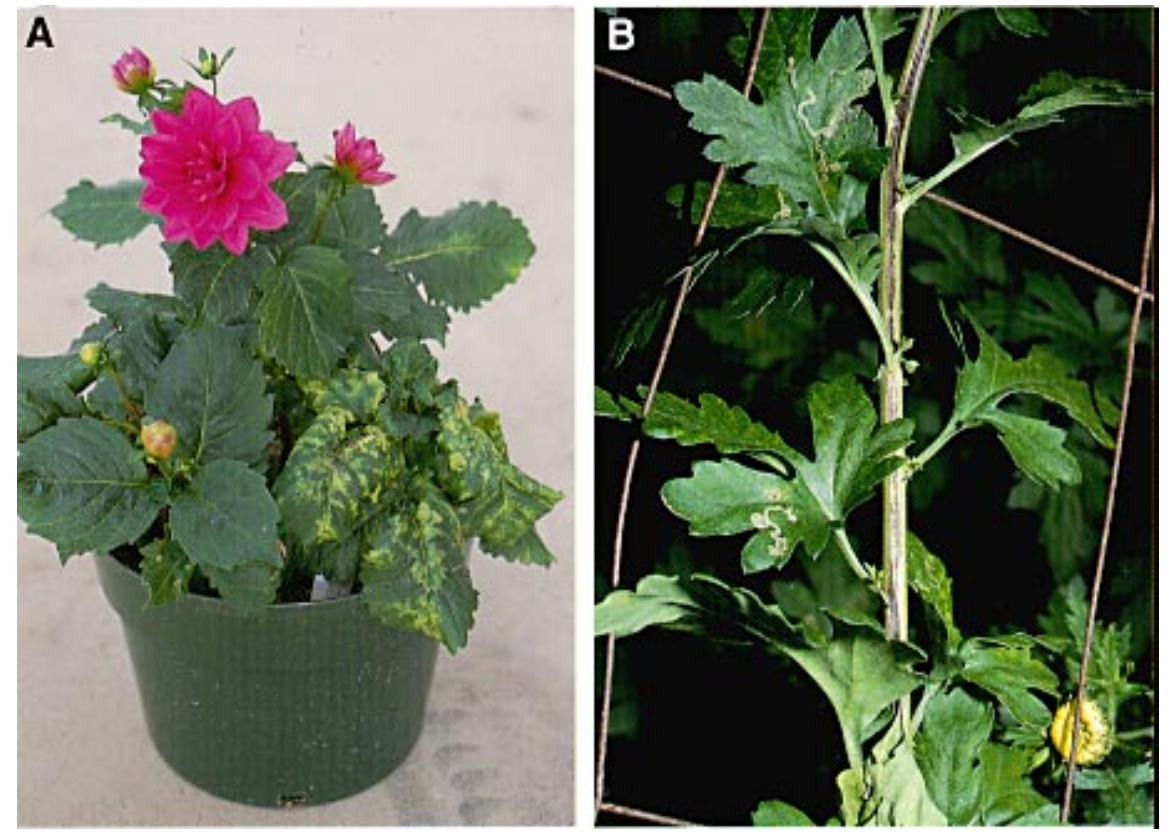

Fig. 5. Symptoms of tomato spotted wilt tospovirus (TSWV) on greenhouse flower crops. (A) Chlorotic mottling and vein banding in dahlia (Dahlia hybrid); (B) stem necrosis in chrysanthemum.

characteristics that distinguish INSV from TSWV now provide the basis upon which individual viruses (species) are classified within the genus Tospovirus. The recognition that multiple viruses existed solved many long-standing mysteries associated with the difficulties of diagnosing and investigating TSWV (14).

INSV is nearly identical to TSWV in general virion morphology (Fig. 8) and genomic organization, which are the criteria used to place viruses in the genus $T o$ spovirus. The INSV virions are quasispherical, consisting of an outer membrane surrounding the genome that is partitioned among three RNA segments labeled S (12), M (21), and L (11).

The S segment contains two open reading frames (ORF) in opposite polarity (ambisense) separated by a large intergenic region. The ORF nearer the $5^{\prime}$ end of the RNA codes for a nonstructural protein in the viral sense designated NSs whose function has not been determined. The NSs protein was shown to be the one that accumulates as paracrystalline fibrils in the cytoplasm. The ORF nearer the 3' end is in the viral complementary sense and codes for the nucleocapsid protein $(\mathrm{Nc})$, which encapsidates the viral RNA within the viral envelope. The Nc protein also accumulates in electron-dense masses in the cytoplasm (Fig.7) and is the predominant protein that antisera recognize. Tospoviruses are classified as distinct viruses or as strains of previously recognized viruses by the degree of similarity in amino acid sequence of the $\mathrm{Nc}$ protein. While sequence of the entire genome is taken into consideration when
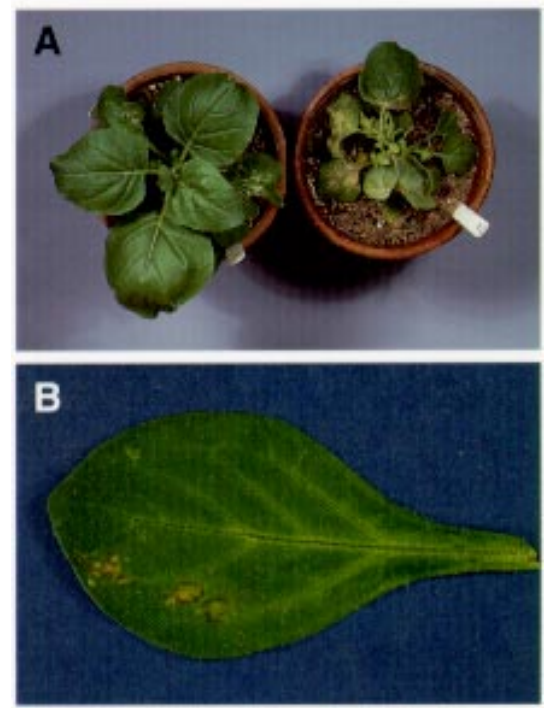

Fig. 6. Indicator plants. (A) Nicotiana benthamiana inoculated with impatiens necrotic spot tospovirus (INSV), showing systemic necrosis and stunting of terminal growth (plant at right is a check); (B) petunia (Petunia $\times$ hybrida Vilm.-Andr.) leaf showing local lesions (black rings) of INSV developing around a thrips feeding site.

Plant Disease / November 1997 1223 
known, only the sequence of the Nc protein is required. It is now widely accepted that isolates with greater than $90 \%$ sequence homology between their respective $\mathrm{Nc}$ proteins are considered strains of the same virus, while isolates with less than 70 to $80 \%$ homology are designated as distinct viruses. More than 10 distinct viruses are now recognized in the genus Tospovirus.

The M RNA is similarly arranged in an ambisense configuration. A nonstructural protein, NSm, proposed to be involved in movement, is coded for by the viral-sense ORF located nearer the $3^{\prime}$ end. The viral complementary sense ORF codes for the G1/G2 precursor protein. G1 and G2 are structural proteins found in the viral envelope. The G1/G2 proteins are more highly conserved between viruses than the $\mathrm{Nc}$ proteins (20). This distant relatedness can result in weak serological reactions in
ELISA when antisera to whole virions are used. Before INSV was discovered, many ELISAs of infected floral crops for TSWV gave weak reactions, only marginally greater than those obtained from assays of healthy tissue. We now suspect that many of those symptomatic plants that gave negative or ambiguous results were actually infected with INSV.

The large RNA has a single ORF in the viral complementary sense, which is a putative RNA-dependent RNA polymerase (11).

\section{The Nature of the Vector}

Thrips that attack plants are relatively small insects (most are 1 to $2 \mathrm{~mm}$ ). The wings are narrow and fringed with long hairs. The mouth parts are piercing-sucking, with only a left mandible. Thrips usually insert eggs into plant tissue. The in-

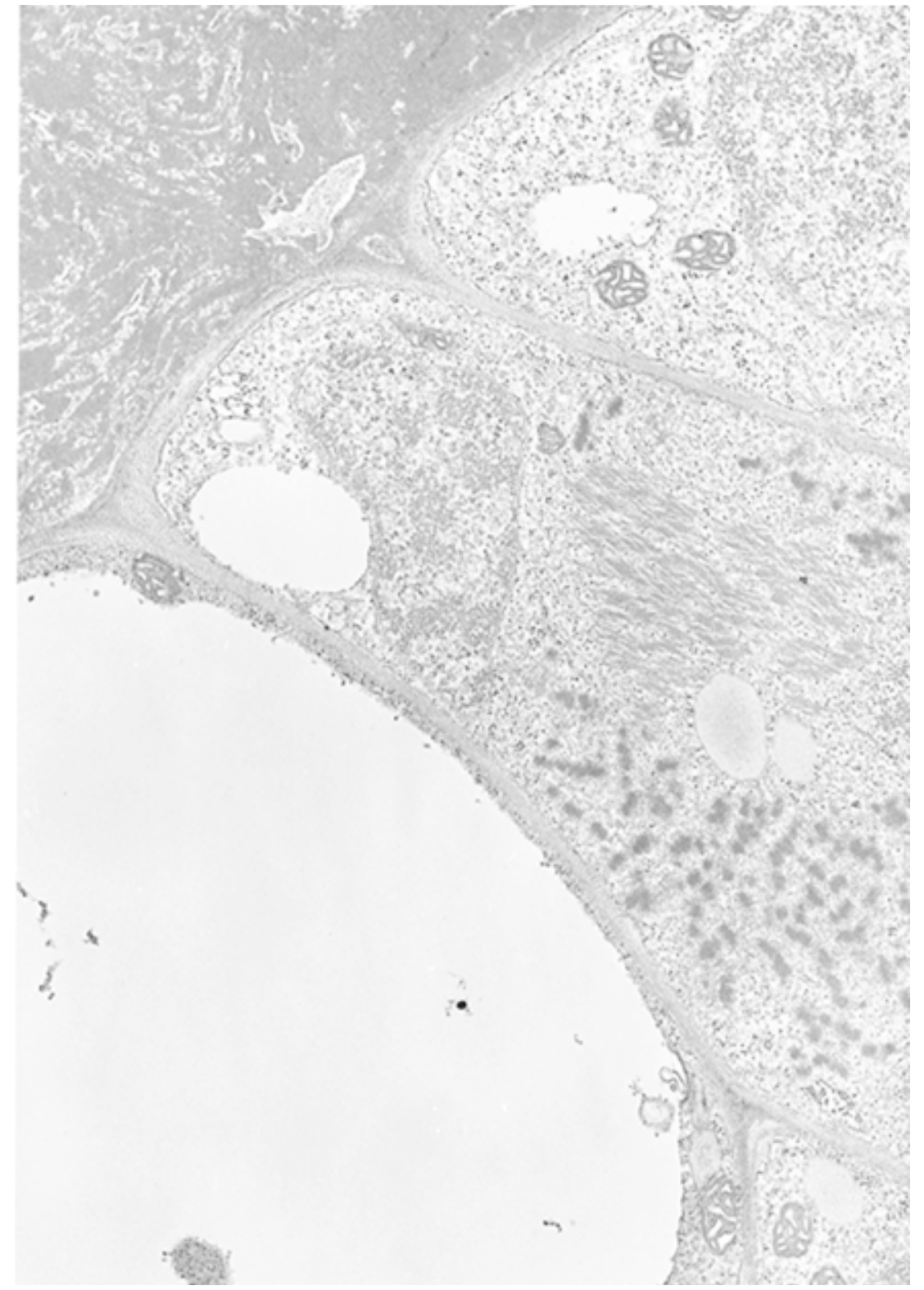

Fig. 7. Impatiens necrotic spot tospovirus (INSV) inclusions. A paracrystalline array of NSs protein appears middle right, above two vacuoles. The electron dense "patches" beneath the vacuoles are nucleocapsid (Nc) protein. sects develop through two larval stages, followed by third (prepupal) and fourth (pupal) stages. The prepupa and pupa do not feed; these stages are often spent on the ground in soil or litter. Thrips can run, crawl, and jump rapidly, and winged adults can fly. Adult thrips can be aerially dispersed by drifting in wind currents for many miles.

TSWV is transmitted by a flower thrips, Frankliniella intonsa (Trybom); cotton bud thrips, Frankliniella schultzei (Trybom); tobacco thrips, Frankliniella fusca (Hinds); the western flower thrips, Frankliniella occidentalis (Pergande); the melon thrips, Thrips palmi Karny; Thrips setosus Moulton; and perhaps the onion thrips, Thrips tabaci Lindeman $(22,27)$. Of these, the western flower thrips (WFT) is the most important TSWV vector (29) and is the only thrips currently known to vector INSV.

The WFT is about $1 \mathrm{~mm}$ long and varies from yellow to dark brown (Fig. 2). The distribution of this species was thought to be limited to west of the Mississippi River prior to 1980 . However, this thrips has extended its range across the southern United States. Some WFT populations have readily adapted to breeding in greenhouses; having acquired resistance to many pesticides, this insect has become the most persistent species attacking greenhouse flowers throughout the United States, Canada, and many countries in Europe and Asia. WFT feeds on almost any flowering plant. Carnations, chrysanthemums, gerberas, geraniums, marigolds, pansies, and roses are among the major hosts.

Damage from WFT feeding and oviposition on flowers and foliage results in scars that reduce the aesthetic quality and marketability of ornamental plants. When thrips feed on developing tissues, the damaged cells are unable to expand, causing mature leaves and petals to be distorted. When thrips feed on expanded tissue, affected cells fill with air, imparting a silvery appearance to the lesions. Thrips inject saliva as they feed: if INSV or TSWV has been acquired from an infected plant by the first-stage WFT larva, the resulting adult carries virus particles in its saliva that can infect new plants (29). TSWV is known to infect the first stage larva and multiply in midgut epithelial cells, muscle cells surrounding the alimentary canal, and the salivary glands (31).

The eggs of WFT hatch in 2 to 14 days, depending on temperature. First-instar larvae (Fig. 9A) begin feeding immediately. Second-instar larvae (Fig. 9B) also feed on plant tissue, usually in flowers. These larvae are usually found in the protection of the perianth of the flower or within developing terminal foliage. Late in the second instar, they stop feeding and move down the plant to pupate. Thrips develop through two quiescent, nonfeeding pupal stages (Fig. 9C) in the soil, in plant 
litter, or in a protected area on the plant. Adults emerge and resume feeding on flowers, buds, and terminal foliage. The entire life cycle from oviposition to adult emergence can take 8 days in hot weather to 44 days in cool weather (24).

\section{Management of the Virus-Vector Complex}

Tospoviruses may be introduced to the of infected plants or viruliferous thrips. Exchange of plant materials is commonplace in the greenhouse industry. Migration of infected thrips from outdoors to the greenhouse interior is a threat, particularly in the southern and western United States, where WFT is now well established. Growers in northern climates may introduce thrips when cuttings or unfinished crops are brought into the greenhouse. Seed transmission, although reported for TSWV on cineraria and tomato, has not been well documented; the ability of INSV to be seed transmitted has not been investigated. Because both WFT and virus sources are often present in a greenhouse, the occurrences of INSV observed in greenhouse flower crops to date have generally had readily traceable origins without any suspicion of seed transmission.

Tospoviruses may easily be maintained within the greenhouse without the grower's knowledge. Weeds on the greenhouse floor or in the plant beds or containers may be reservoirs of INSV or TSWV, regardless of whether they exhibit symptoms. Chickweed (Stellaria media L.), oxalis (Oxalis sp.), jewelweed (Impatiens capensis Meerb.), bittercress (Barbarea vulgaris R. Br.), gillover-the-ground (Glechoma hederacea L.), and galinsoga (Tridax trilobata (Cav.) Hemsl.) growing as weeds in greenhouses have tested positive by ELISA for INSV greenhouse repeatedly via the movement

(30). Crops begun in the fall growing season, such as holiday cactus or cyclamen, may bridge tospoviruses over to the spring bedding plant production season. When the population of the thrips vector rises dramatically in the spring, bedding plants are young and rapidly growing and will develop severe symptoms if infected. A few unsold diseased plants from a fall crop may thus pose a serious threat to spring crops. Growers who maintain stock of vegetatively propagated plants such as Swedish ivy (Plectranthus australis $\mathrm{R}$. Br.) may be maintaining virus cultures as well. Some plants maintained perennially in the greenhouse, such as Stephanotis (Stephanotis floribunda (R. Br.) Brongn.), may serve as reservoirs for tospoviruses.

It is the ability of the viruses to be transmitted both directly by the common vector WFT and indirectly by the movement of infected propagation material that causes them to be major problems in the greenhouse industry. The only controls available at present are directed at blocking these two avenues of spread. Quick responses to thrips population increases and virus symptom appearance are critical to disease management. Two simultaneous approaches are necessary to obtain effective control of INSV: virus exclusion and elimination of spread.

Excluding the virus by utilizing virusindexed propagation material from certain suppliers is possible for some of the highly susceptible crops. Nuclear stock must be routinely screened by serologically specific tests for INSV and TSWV, or by testing on sensitive indicator hosts such as $N$. benthamiana. The nuclear stock is maintained in limited-access facilities screened with fine mesh to exclude thrips. In some areas of the country, screening may even be necessary when crops are

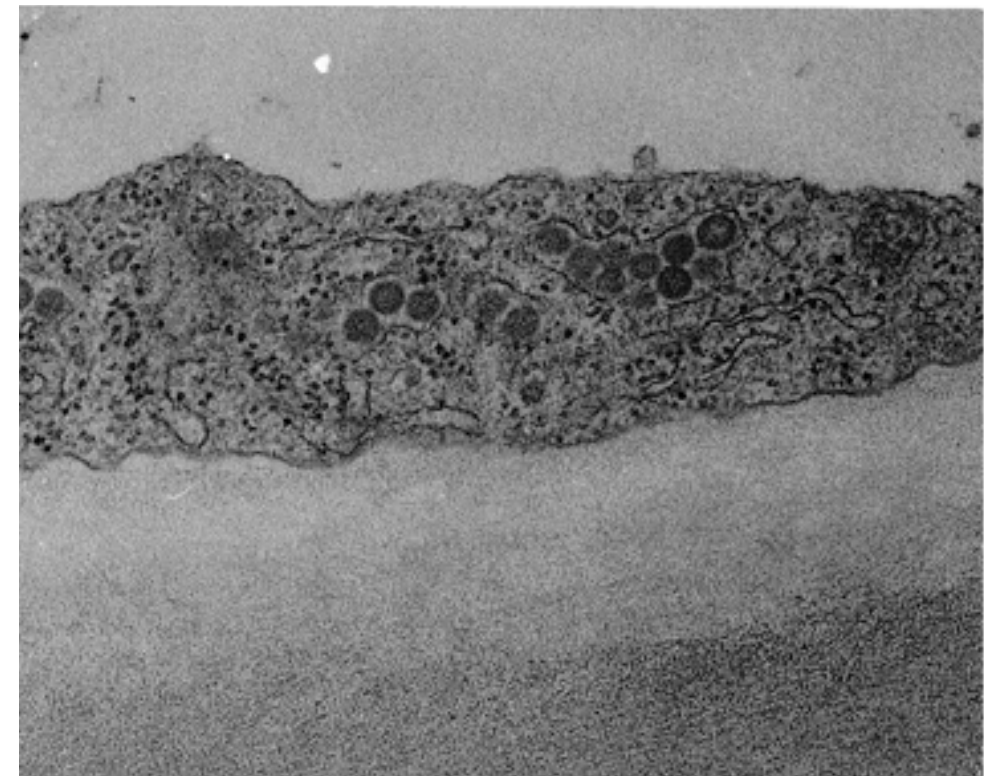

Fig. 8. Impatiens necrotic spot tospovirus (INSV) virions (80 to $120 \mathrm{~nm}$ ) clustered in groups surrounded by an outer membrane, as is typical for tospoviruses. being finished from the nuclear stock, in order to avoid introduction of a tospovirus from thrips migrating from outside. Screening can significantly reduce numbers of insects flying into greenhouses (3). A screen with aperture diameters no greater than 135 microns is needed to exclude thrips, but this fine mesh significantly decreases air flow into the greenhouse. Increased vent surface area and active ventilation are used to compensate (Fig. 10). Growers can avoid carrying insects into the greenhouse by not wearing the colors white, blue, yellow, or green. Aphids, thrips, and whiteflies are attracted to yellow, green, and blue. Thrips are also attracted to white.

The second category of disease control measures is the elimination of spread within the production area, preventing widespread epidemics after introduction of virus. Here, the focus is on elimination of the resident population of thrips and on roguing all of the INSV- or TSWV-symptomatic plant material from the production area. Symptomatic plants (crops or weeds) should be gently placed into sealed bags as they are collected for removal to prevent dislodging possibly viruliferous thrips. Virus-infected plants have been shown to be more susceptible to thrips feeding and oviposition than uninfected plants (5), so their prompt removal is especially critical.
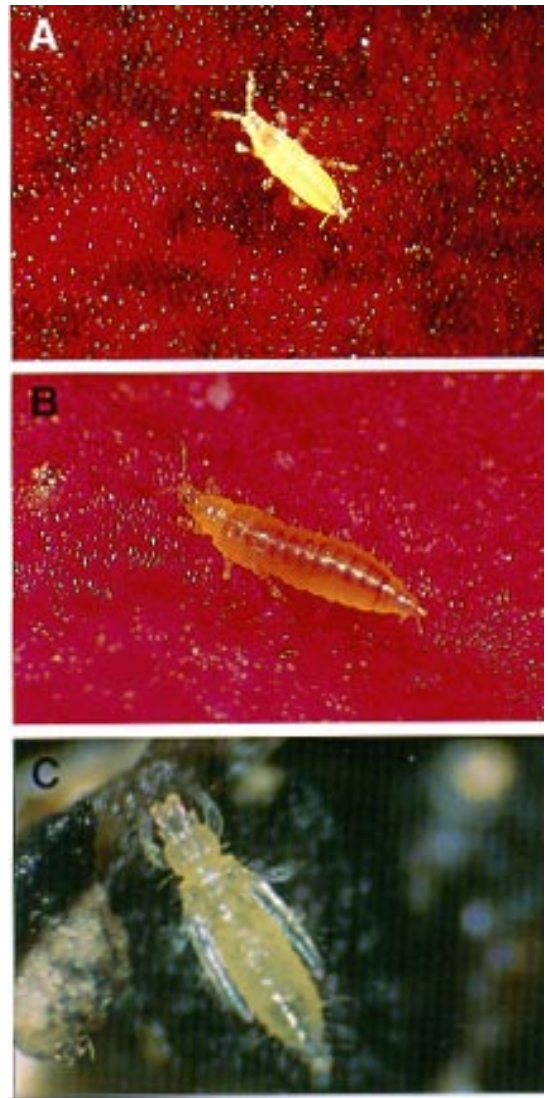

Fig. 9. Early developmental stages of Western flower thrips. (A) First-stage larva, which acquires the virus; (B) second-stage larva; (C) pupa. 
Robb and Parrella (23) first reported that screening the greenhouse to prevent the introduction of thrips from outside was effective. Their thrips control recommendations are still appropriate: (i) screen the vents and doors; (ii) isolate the breeding and stock areas from production areas; (iii) introduce only clean cuttings into the production area; (iv) treat the soil between crops; (v) educate workers to recognize thrips during disbudding, transplanting, and so on; (vi) try to keep plants as near the same age as possible in each house; (vii) spray all the plants in an area at one time; (viii) group the most sensitive varieties together; (ix) keep sensitive varieties away from doors and vents; (x) monitor thrips populations with yellow or white sticky cards; (xi) put traps near doors and sensitive plants; (xii) keep records of populations for evaluating pesticide efficacy and future use; (xiii) eradicate weeds around the greenhouse; (xiv) dispose of

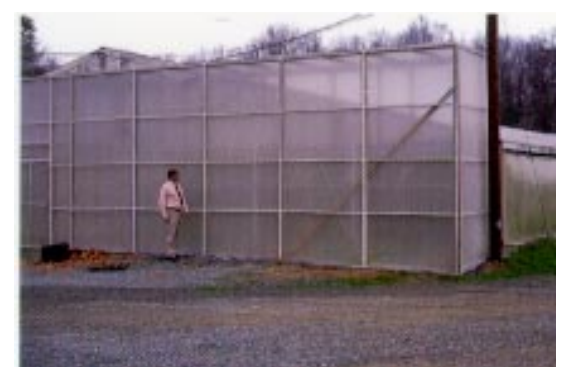

Fig. 10. Thrips exclusion screening. Porchlike addition at end of greenhouse provides increased surface area, which is necessary to compensate for reduced air flow. plant residues in a timely manner; and (xv) use pesticides judiciously.

All plant material should be inspected before it is brought into the greenhouse and preferably kept in a separate section for a week or more before incorporating the new material into the production area, to assure that thrips are not introduced into the main production area. Sticky cards may be used to detect thrips infestations in new material.

To stay aware of the potential virusvector population in the greenhouse, it is important to constantly monitor the thrips numbers in the greenhouse by using sticky cards. Yellow, white, or blue sticky cards should be spaced at a density of at least one card for every 1,000 square feet of growing area. Insects on the cards can be clearly distinguished with the aid of a $5 \times$ to $10 \times$ loupe. The cards should be positioned vertically, with the bottom of the card near the top of the crop. The cards can be moved upward as the crop grows taller, but the location of the card should stay the same from week to week. Sticky cards should be examined daily, and counts of newly trapped thrips should be recorded one to two times per week. Since the transmission of tospoviruses is highly efficient, the tolerance for thrips as virus vectors is very low. Propagators will have a zero tolerance for thrips. Even growers who finish crops (as opposed to propagators) typically use counts of 10 thrips per week per 1,000 square feet as a threshold value that signals initiation of spray treatment. For the most efficient reduction of virus spread, the goal is to respond promptly to a new flush of thrips adults, so they can be killed before they have the opportunity to lay eggs or feed.
As a supplement to the use of sticky cards to monitor WFT population levels, indicator plants may be used to monitor more specifically for the presence of tospovirus-carrying thrips (1). Petunia $\times$ hybrida 'Summer Madness' and 'Super Magic Coral' (Ball Seed Co., West Chicago, IL) and 'Red Cloud' (Goldsmith Seed Co., Gilroy, CA) are all good indicators of INSV and TSWV. Dwarf cultivars of fava bean (including the cultivar Aquadulce) (Stokes Seed, Ontario, Canada) are also useful as indicator plants. To enhance the attractiveness of the indicator plant, a yellow or blue (nonsticky) card is added to the container on a plant stake. The transmission of a tospovirus is signaled by the appearance of a dark-rimmed lesion around the whitish feeding scar of the thrips. The use of indicator plants is particularly valuable in assessing whether viruliferous thrips still remain in a greenhouse before a new crop is introduced and in giving early warning of tospovirus in a crop that is very slow to develop symptoms, such as cyclamen.

WFT has acquired resistance to many insecticides (24) and breeds successfully in many greenhouses all year long, so that flower growers often have an extraordinarily difficult time getting good control. Thrips move deeply into the blossoms and buds and avoid the pesticide. Because systemic insecticides do not readily translocate into the buds and flowers of ornamental plants, blossoms cannot be protected by applying systemic pesticides to the potting mix. Eggs (inserted in plant tissue) and pupae (predominantly on the soil surface) are nonfeeding stages of the life cycle that thus cannot be directly tar-
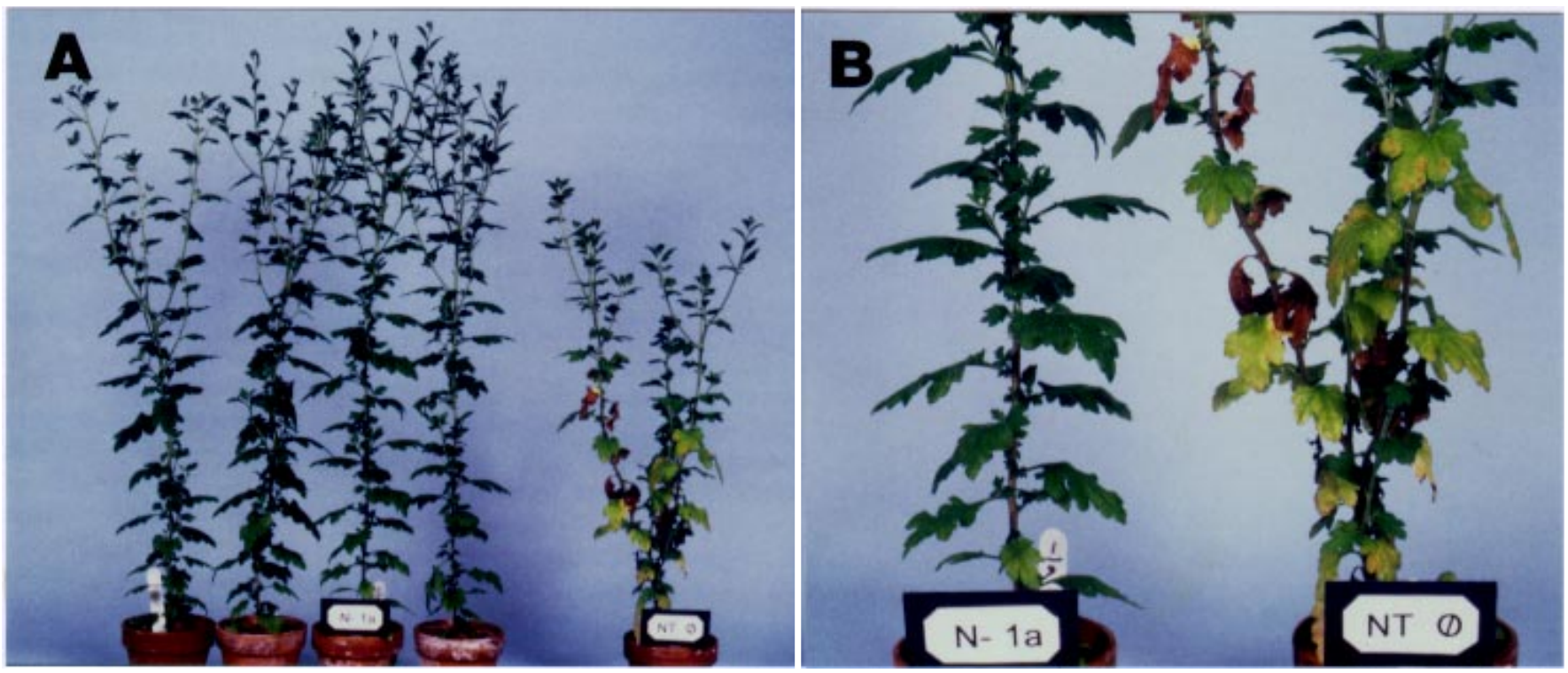

Fig. 11. Genetically engineered resistance to tomato spotted wilt tospovirus (TSWV) in chrysanthemum cultivar Polaris. (A) Uniformity of resistance. Symptoms and pronounced stunting caused by TSWV on a nontransformed control plant (right) as contrasted with the uniform lack of symptoms on four plants derived from a transgenic Polaris plant transformed with an antisense construct of the TSWV Nc gene (left). (B) Close-up of symptoms. Nontransformed (NT) plant showing pronounced necrotic and chlorotic leaf symptoms and multiple shoots resulting from apical bud death on the initial shoot due to TSWV infection. Transformed Polaris plant ( $\mathrm{N}-1 \mathrm{a})$ shows no symptoms and a single shoot typical of the growth habit of this cut-flower chrysanthemum cultivar. 
geted by sprays. For this reason, it necessary to apply two or three insecticide treatments for thrips, spaced 3 to 5 days apart, once sticky card monitoring shows that the action threshold has been reached.

Naled (Dibrom) as a fumigant was reported to give $100 \%$ control of adult thrips, while microencapsulated chlorpyrifos (Duraguard), diazinon (Diazinon), acephate (Orthene), and endosulfan (Thiodan) sprays reportedly gave good control (23). Formetanate (Carzol) 92\% soluble powder has a special local needs registration in some states for WFT control on ornamental plants in the greenhouse (2). Methiocarb (Mesurol) has been reported to give fair to good control. Bendiocarb (Dycarb) has been effective in some trials, but Zhao et al. (32) reported WFT resistance to bendiocarb among populations in Missouri. Pyrethroids have performed poorly overall; Immaraju et al. (18) reported high levels of resistance to pyrethroids in California WFT populations. Although it had been suggested that sugar added to sprays would lure the insects to more exposed locations on the plant, our demonstrations have not shown any benefit of sugar additives to thrips insecticides. Avermectin (Avid), which is registered for leafminer and spider mite control, reduces WFT feeding when applied to flowers and foliage (M. Parrella, unpublished data).
In order to impede the development of resistance to insecticides, it is recommended that growers rotate among classes of insecticides with different modes of action rather than using only one pesticide time after time. A material should be used three times at 3- to 5-day intervals before switching to another class of insecticides.

Natural enemies have been investigated, and biological control programs using entomopathogens (7) and predaceous plant bugs and mites are still being studied (26). Unfortunately, control of the WFT is likely to continue to be difficult and costly in the foreseeable future.

\section{Engineering Flower Crops for Resistance to Tospoviruses}

Control of tospoviruses in floral crops would benefit by the development of resistant cultivars in major floral crop species. However, breeding for virus resistance in floral crops has traditionally been hampered by the diversity of species, the lack of identified sources of resistance genes, the overriding importance of horticultural traits, and the rapid turnover of popular cultivars (8). Given these constraints, genetic engineering perhaps holds the best potential for the development of resistance to tospoviruses in floral crops, particularly given the extensive studies on the effectiveness of genetic engineering for tospovirus resistance in tobacco and vegetable crops. Numerous reports have documented the effectiveness of transforming plants with the nucleocapsid $(\mathrm{Nc})$ gene of TSWV, INSV, and other tospoviruses for the development of resistant plants $(15,19)$.

The ability to genetically engineer floral crops depends first on the development of protocols that allow for high-frequency shoot regeneration from explant tissues. Shoot regeneration then needs to be coupled with an effective gene transfer vehicle, most commonly the use of Agrobacterium vectors or biolistic ("gene gun") transformation. Although techniques for genetically engineering floral crops have lagged behind those for major food crops, significant efforts have been made in recent years. Currently, many of the major floral crops (rose, chrysanthemum, carnation, lily, tulip, gerbera, and geranium) have been successfully transformed (13), resulting in altered phenotypes (most notably flower color) (10). To date, there are few reports of genetically engineered disease resistance in floral crops.

For the last several years, we have worked at North Carolina State University to develop tospovirus-resistant floral crops via transformation of plants with the TSWV and INSV Nc protein genes $(8,25)$. Chrysanthemum was chosen as the model system for this work since it is economi-

An advertisement appears in the printed journal in this space. 
cally important and highly susceptible to TSWV, and extensive studies had been done on the development of in vitro culture and transformation protocols. We developed a high-frequency regeneration and Agrobacterium-mediated transformation protocol that relied on the use of embryogenesis regeneration media and was applicable to multiple cultivars of chrysanthemum $(25,28)$. Using this procedure, we produced more than 200 chrysanthemum plants transformed with the TSWV Nc gene.

Transformed plants were tested for resistance to TSWV by both thrips and mechanical inoculation. Initially, cuttings from transformed plants were incubated in a greenhouse chamber that contained thrips reared on TSWV-infected chrysanthemum and Datura plants. Thrips were allowed to feed continuously on the transformed plants for 10 weeks, after which infection was assessed by observation of symptoms and by ELISA analysis of upper leaves. All plants developed small chlorotic lesions at thrips feeding sites on the lower leaves of the plants. However, approximately $13 \%$ of the plants lacked any systemic symptoms (veinal necrosis, stem cankers, apical bud death) and had negative ELISA values. By contrast, all control plants developed extensive and severe systemic symptoms (Fig. 11). These results are similar to those we have obtained with transgenic tobacco plants, where local lesions develop on the initial inoculated leaves but plants are resistant to systemic spread of the virus.

Cuttings from chrysanthemum plants that lacked systemic symptoms and lacked detectable virus by ELISA were then tested by mechanical inoculation. Plants were inoculated three times and observed for the development of symptoms for 16 weeks. Many of the plants that were scored as resistant in the thrips test developed symptoms when subjected to this stringent mechanical inoculation test, but nine lines were identified that either developed no systemic symptoms or lacked the most severe systemic symptoms (stem cankers and apical bud death). These lines are currently being evaluated by the greenhouse flower industry. Other lines showed reduced symptoms and delayed symptom development. It is possible that many of these additional lines would also have utility for TSWV control as part of an integrated management program.

Many questions remain to be answered about the utility of transgenic resistance for tospovirus control in floral crops. It is known, for example, that $\mathrm{N}$-gene mediated resistance can be overcome by distantly related strains of the virus. Also, the stability of transgenic resistance in vegetatively propagated crops and the commer- cial acceptability of these plants have not been extensively investigated. Nevertheless, the outlook for the development and use of transgenic floral crops is positive given the recent advances in the development of transformation technologies. Also, since floral crops are not food crops, it may be easier to gain consumer acceptance. The floral industry is in a good position to take advantage of this technology, as it has always played a leadership role in agriculture in the use of in vitro culture technology and the application of new and novel pest control practices.

\section{Literature Cited}

1. Allen, W. R., and Matteoni, J. A. 1991. Petunia as an indicator plant for use by growers to monitor for thrips carrying the tomato spotted wilt virus in greenhouses. Plant Dis. 75:7882.

2. Baker, J. R., and Bailey, D. A. 1996. Pesticides labeled for greenhouse ornamental insect and related pest control. N.C. Flower Growers' Bull. 41(5):5-20.

3. Baker, J. R., Bethke, J. A., and Shearin, E. A. 1995. Insect Screening. Pages 155-170 in: New Guinea Impatiens: A Ball Guide. W. Banner and M. Klopmeyer, eds. Ball Pub. Batavia, IL.

4. Bandla, M. D., Westcot, D. M., Chenault, K. D., Ullman, D. E., German, T. L., and Sherwood, J. L. 1994. Use of monoclonal antibody to the nonstructural protein encoded by the small RNA of tomato spotted wilt tospovirus to identify viruliferous thrips. Phytopa-

An advertisement appears in the printed journal in this space. 


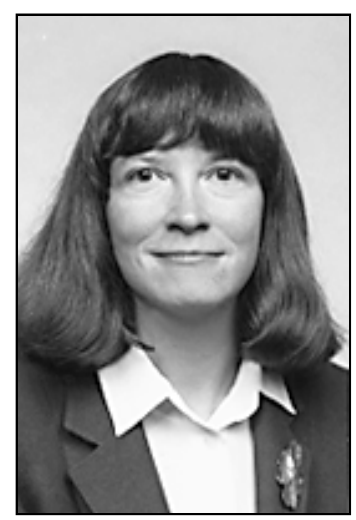

Margery L. Daughtrey

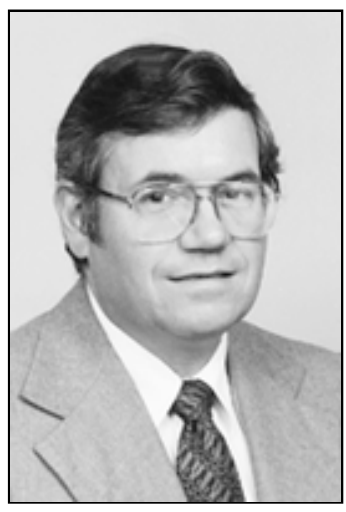

Ronald K. Jones

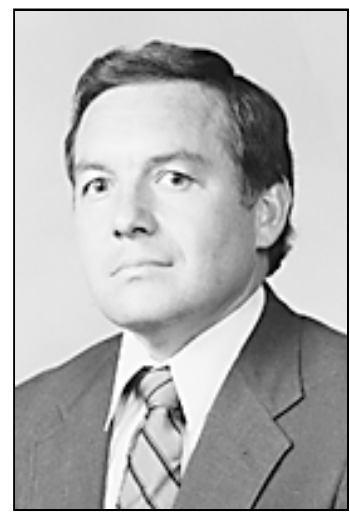

James W. Moyer

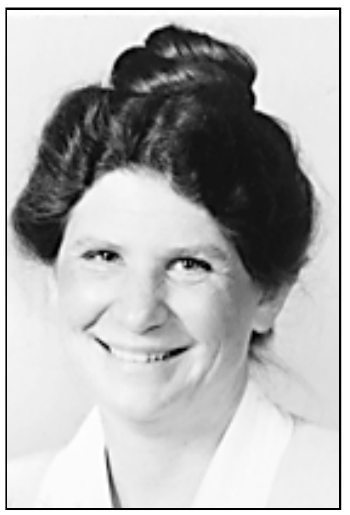

Margaret E. Daub

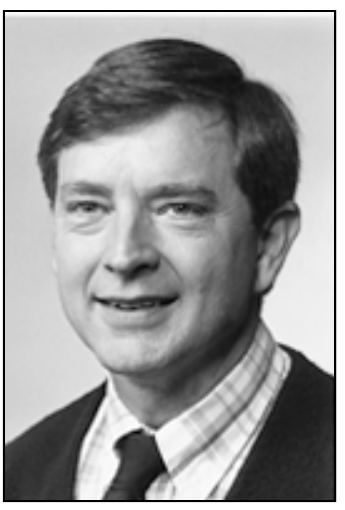

James R. Baker

\section{Margery L. Daughtrey}

Ms. Daughtrey, senior extension associate with the Department of Plant Pathology, Cornell University, has conducted a research and extension program on the management of diseases of ornamental plants for the past 19 years. She is stationed at the Long Island Horticultural Research Laboratory in Riverhead, New York, where she diagnoses greenhouse and nursery crop diseases and develops management strategies for problems such as powdery mildew, Fusarium wilt, root rots, and tospoviruses. Ms. Daughtrey holds a B.S. in biology from the College of William and Mary and an M.S. in plant pathology from the University of Massachusetts. She is coauthor of the Compendium of Flowering Potted Plant Diseases produced by APS Press.

\section{Ronald K. Jones}

Dr. Jones is a full professor and departmental extension leader in plant pathology at North Carolina State University. He received his B.S. in ornamental horticulture from VPI in 1961, his M.S. in plant pathology from the University of Delaware, and his Ph.D. in plant pathology from VPI in 1971. He was an extension specialist at Clemson University from 1965 to 1968, with responsibilities in ornamentals and fruit. Dr. Jones has been in extension at North Carolina State University since 1970 with responsibilities in ornamentals and some small fruits.

\section{James W. Moyer}

Dr. Moyer is professor of plant pathology at North Carolina State University. He received his undergraduate degree in agronomy from Washington State University and his M.S. and Ph.D. degrees in plant pathology from Pennsylvania State University. He joined the faculty at North Carolina State
University in 1976. Initially, he conducted research on diseases of sweet potato and cooperated with the breeder in cultivar development. More recently, his research has been focused on virus resistance and on the molecular biology of Tospoviruses. The discovery and characterization of impatiens necrotic spot virus provides the basis of the current classification system of Tospoviruses. He recently completed a 3-year term as interim head of the biochemistry department.

\section{Margaret E. Daub}

Dr. Daub is a professor of plant pathology at North Carolina State University. She received her Ph.D. in plant pathology from the University of Wisconsin-Madison in 1979, followed by postdoctoral work at Michigan State University. She joined the faculty at NCSU in 1983, where she focused on the use of plant cell culture and genetic engineering for the development of disease resistance. Currently, she conducts research on coatprotein mediated resistance to tomato spotted wilt virus in tobacco and floral crops. She also has an active program on light-activated fungal toxins and their involvement in disease. She presently serves as editor-in-chief of Phytopathology and as chair of the APS publications board.

\section{James R. Baker}

Dr. Baker, professor of extension entomology at North Carolina State University, for 25 years has been responsible for training county agents to recognize and respond correctly to complaints about insect pests of ornamental plants. He has edited a series of six identification manuals for county agents and commercial growers. One, "Insects and Related Pests of Flowers and Foliage Plants," has been posted on the World Wide Web and is available in Spanish. His lab has done research on screening greenhouses for pest exclusion that led to the development of a computer program for fitting more than 30 kinds of fabrics onto greenhouses to exclude pests yet allow adequate ventilation. 
thology 84:1427-1431.

5. Bautista, R. C., Mau, R. F. L., Cho, J. J., and Custer, D. M. 1995. Potential of tomato spotted wilt tospovirus plant hosts in Hawaii as virus reservoirs for transmission by Frankliniella occidentalis (Thysanoptera: Thripidae). Phytopathology 85:953-958.

6. Brown, L., Simone, G. W., and Christie, R. G. 1991. Diagnostic strategy development for tomato spotted wilt virus. Pages 94-100 in: Virus-thrips-plant interactions of tomato spotted wilt virus. H. Hsu and R. H. Lawson, eds. U.S. Dep. Agric., Agric. Res. Serv., ARS87.

7. Brownbridge, M., McLean, D., Parker, B., and Skinner, M. 1994. Use of fungal pathogens for insect control in greenhouses. Pages 7-20 in: Proc. Conf. Insect Dis. Manage. Ornamentals, 10th. Society of American Florists, Alexandria, VA.

8. Daub, M. E., Jones, R. K., and Moyer, J. W. 1997. Biotechnological approaches for virus resistance in floral crops. Pages 335-351 in: Biotechnology of Ornamental Plants. R. L. Geneve, J. E. Preece, and S. A. Merkle, eds. CAB International, Wallingford, Eng.

9. Daughtrey, M. 1996. Detection and identification of tospoviruses in greenhouses. Acta Hortic. 431:90-98.

10. Davies, K. M., and Schwinn, K. E. 1997. Flower Colour. Pages 259-294 in: Biotechnology of Ornamental Plants. R. L. Geneve, J. E. Preece, and S. A. Merkle, eds. CAB International, Wallingford, Eng.

11. de Haan, P., Kormelink, R., Resende, R., van Poelwijk, F., Peters, D., and Goldbach, R. 1991. Tomato spotted wilt virus L RNA encodes a putative RNA polymerase. J. Gen. Virol. 71:2207-2216.

12. de Haan, P., Wagemakers, L., Peters, D., and Goldbach, R. 1990. The S RNA segment of tomato spotted wilt virus has an ambisense character. J. Gen. Virol. 71:1001-1007.

13. Deroles, S. C., Boase, M. R., and Konczak, I. 1997. Transformation protocols for ornamental plants. Pages 87-119 in: Biotechnology of
Ornamental Plants. R. L. Geneve, J. E. Preece, and S. A. Merkle, eds. CAB International, Wallingford, Eng.

14. German, T. L., Ullman, D. E., and Moyer, J. W. 1992. Tospoviruses: Diagnosis, molecular biology, phylogeny, and vector relationships. Annu. Rev. Phytopathol. 30:315-348.

15. Gonsalves, D., Pang, S. Z., Gonsalves, C., Xue, B., Yepes, M., and Jan, F. J. 1996. Developing transgenic crops that are resistant to tospoviruses. Acta Hortic. 431:427-431.

16. Hausbeck, M. K., Welliver, R. A., Derr, M. A., and Gildow, F. E. 1992. Tomato spotted wilt virus survey among greenhouse ornamentals in Pennsylvania. Plant Dis. 76:795800.

17. Hsu, H., and Lawson, R. H. 1991. Detection of tomato spotted wilt virus by enzyme-linked immunosorbent assay, dot-blot immunoassay and direct tissue blotting. Pages 120-126 in: Virus-thrips-plant interactions of tomato spotted wilt virus. H. Hsu and R. H. Lawson, eds. U.S. Dep. Agric., Agric. Res. Serv., ARS87.

18. Immaraju, J. S., Paine, T. D., Bethke, J. A., Robb, K. L., and Newman, J. R. 1992. Western flower thrips (Thysanoptera:Thripidae) resistance to insecticides in coastal California greenhouses. J. Econ. Entomol. 85:9-14.

19. Kim, J. W., Sun, S. S. M., and German, T. L. 1994. Disease resistance in tobacco and tomato plants transformed with the tomato spotted wilt virus nucleocapsid gene. Plant Dis. 78:615-621.

20. Law, M. D., and Moyer, J. W. 1990. A tomato spotted wilt-like virus with a serologically distinct N protein. J. Gen. Virol. 71:933-938.

21. Law, M. D., Speck, J., and Moyer, J. W. 1992 The nucleotide sequence and genomic organization of the impatiens necrotic spot tospovirus M RNA. Virology 188:732-741.

22. Mound, L. A. 1996. The Thysanoptera vector species of tospoviruses. Acta Hortic. 431:298309.

23. Robb, K., and Parrella, M. 1988. Chemical and non-chemical control of western flower thrips. Pages 94-103 in: Proc. Conf. Insect Dis. Manage. Ornamentals, 4th. Society of American Florists, Alexandria, VA.

24. Robb, K., Parrella, M. P., and Neuman, J. P. 1988. The biology and control of the western flower thrips. Part 1. Ohio Florists' Assoc. Bull. 699:2-5

25. Sherman, J. M., Moyer, J. W., and Daub, M. E. 1996. Genetic engineered resistance to tomato spotted wilt virus in chrysanthemum (Dendranthema grandiflora): A model system for virus protection in ornamental crops. Acta Hortic. 431:432-441.

26. Steiner, M. Y., and Goodwin, S. 1996. Integrated control in greenhouses in Australia: Summary of paper presented in Vienna. Sting, Newsletter on Biological Control in Greenhouses. 16:6-7. Wageningen.

27. Ullman, D. E. 1996. Thrips and tospoviruses: Advances and future directions. Acta Hortic. 431:310-324.

28. Urban, L. A., Sherman, J. M., Moyer, J. W., and Daub, M. E. 1994. High frequency shoot regeneration and Agrobacterium-mediated transformation of chrysanthemum (Dendranthema grandiflora). Plant Sci. 98:69-79.

29. van de Wetering, F., Goldbach, R., and Peters, D. 1996. Transmission of tomato spotted wilt virus by Frankliniella occidentalis after viral acquisition during the first larval stage. Acta Hortic. 431:350-358

30. Wick, R. L., Smith, T., Lopes, P., and Haviland, P. 1997. 1996 greenhouse survey for impatiens necrotic spot virus. Floral Notes, University of Massachusetts Extension, Plant and Soil Science 9:11-12.

31. Wijkamp, I., van Lent, J., Kormelink, R., Goldbach, R., and Peters, D. 1993. Multiplication of tomato spotted wilt virus in its insect vector, Frankliniella occidentalis. J. Gen. Virol. 74:341-349.

32. Zhao, G., Liu, W., and Knowles, C. O. 1995. Mechanisms conferring resistance of western flower thrips to bendiocarb. Pestic. Sci. 44:293-297. 